Check for updates

Cite this: RSC Adv., 2019, 9, 23295

Received 26th April 2019

Accepted 22nd July 2019

DOI: 10.1039/c9ra03135a

rsc.li/rsc-advances

\section{Synthesis, functionalization, and isolation of planar-chiral pillar[5]arenes with bulky substituents using a chiral derivatization agent $\uparrow$}

\author{
Talal F. Al-Azemi, (D)* Mickey Vinodh, Fatemeh H. Alipour \\ and Abdirahman A. Mohamod
}

Bulky perneopentyloxy-pillar[5]arene (Pillar-1) was synthesized and its conformational mobility was investigated using variable-temperature ${ }^{1} \mathrm{H}$ NMR spectroscopy. The host-guest interactions between Pillar-1 and n-octyltrimethylammonium hexafluorophosphate (OMA) were investigated, and the formation of a 1:1 complex was revealed via ${ }^{1} \mathrm{H}$ NMR. Planar-chiral isomers were synthesized via the reaction of a hydroxy-functionalized pillar[5]arene with chiral derivatization agent (S)-(+)-MTPA-Cl. The $(\mathrm{Sp}, R)$-and $(\mathrm{Rp}, R)$-forms of the pillar[5]arene diastereomers were isolated by HPLC, and their structures were analyzed by ${ }^{19} \mathrm{~F}$ NMR. HPLC measurements indicated that racemization did not take place at $40{ }^{\circ} \mathrm{C}$ for $72 \mathrm{~h}$.

\section{Introduction}

Examples of macrocyclic host molecules are crown ethers, ${ }^{1}$ calixarenes,${ }^{2}$ cucurbiturils, ${ }^{3}$ cyclodextrins,${ }^{4}$ cyclophanenes ${ }^{5}$ and their structurally similar scaffolds. ${ }^{6}$ Pillararenes, a relatively new class of macrocyclic compounds, have garnered considerable attention recently due to their interesting conformational, physicochemical, and host-guest properties. ${ }^{7}$ Pillararenes and their derivatives are good hosts for a variety of organic compounds such as viologens, ${ }^{8 a}$ alkanediamines, ${ }^{8 b}$ dinitrobenzene, ${ }^{8 c}$ azobenzene derivatives, ${ }^{8 d}$ and neutral molecules. ${ }^{8 e-g}$ Functionalized pillararenes provide a useful platform for the construction of various interesting supramolecular systems and functionalization enables tuning of certain physical properties such as solubility, optical response, and crystallinity. Functionalized pillar[5]arenes bearing bromo, ${ }^{9 a}$ amino, ${ }^{9 b}$ alkyne, ${ }^{9 c}$ and hydroxy groups ${ }^{10-12}$ have been synthesized using different methods such as controlled de-O-methylation, ${ }^{9 a}$ selective oxidation-reduction, ${ }^{10}$ or by co-cyclization with a functional monomer. ${ }^{11,12}$

Recently, planar-chiral pillar[5]arene enantiomers with bulky percyclohexylmethyl-substituents were successfully isolated using chiral column HPLC. The bulky substituents on both rims play an important role in inhibiting the rotational motion round the units. ${ }^{7 d}$ Notably, planar-chiral molecules have been widely used as chiral auxiliaries and ligands for transition

Chemistry Department, Kuwait University, P. O. Box 5969, Safat 13060, Kuwait. E-mail: t.alazemi@ku.edu.kw; Fax: +965-2481-6482; Tel: +965-2498-554

$\dagger$ Electronic supplementary information (ESI) available. CCDC 1561385. For ESI and crystallographic data in CIF or other electronic format see DOI: 10.1039/c9ra03135a metal-catalyzed asymmetric reactions. In addition, planarchiral molecules have many potential applications as scaffolds for chiral guest receptors and architectures for chiral supramolecular assemblies and polymers. ${ }^{13}$ Appropriate structural modifications of the receptors are always necessary in order to tune the guest encapsulation and reactivity. Although chiralplanar pillar[5]arenes have been isolated by restricting the rotation around the units with bulky groups of cyclohexylmethyl groups, the synthesis and isolation of functionalized chiralplanar pillar[5]arenes with different bulky groups has not been reported. Herein, we report the synthesis of pillar[5]arenes with bulky perneopentyl groups, as well as their variabletemperature ${ }^{1} \mathrm{H}$ NMR measurements, and guest-binding properties. The derivatization, isolation, and characterization of chiral-planar functionalized pillar[5]arenes with $(S)-(+)-\alpha-$ methoxy- $\alpha$-trifluoromethylphenylacetyl chloride $((S)-(+)-$ MTPA$\mathrm{Cl})$ are also reported.

\section{Results and discussion}

\section{Synthesis}

1,4-Bis(neopentyloxy)benzene was synthesized via the reaction of 1-iodo-2,2-dimethylpropane with hydroquinone in DMF in the presence of $\mathrm{K}_{2} \mathrm{CO}_{3}$ at $120^{\circ} \mathrm{C}$ in a sure seal tube. Despite the 10 bulky groups on both rims, perneopentyloxy-pillar[5]arene (Pillar-1) was synthesized by cyclization of 1,4-bis(neopentyloxy)benzene with paraformaldehyde in the presence of $\mathrm{BF}_{3^{-}}$ - $\mathrm{OEt}_{2}$, according to the literature procedure shown in Scheme $1 .^{a}{ }^{a}$ In contrast, bulky percyclohexylmethyl pillar[5]arene was synthesized by the reaction of perhydroxypillar[5]arene with (bromomethyl)cyclohexane. ${ }^{7 d}$ Suitable crystals for X-ray single crystal diffraction analysis were grown by slow diffusion of 


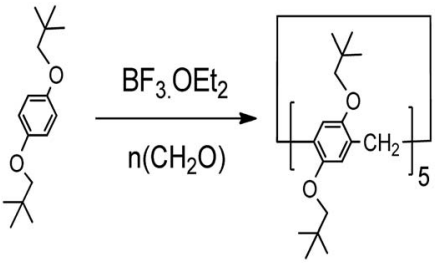

Pillar-1

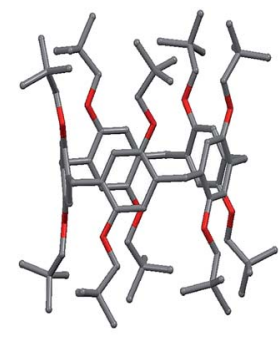

X-Ray crystal
Scheme 1 Synthesis of perneopentyloxy-pillar[5]arene (Pillar-1), and $\mathrm{X}$-ray crystal structure.

hexane into a solution of Pillar-1 in dichloroethane. In the solid state, Pillar-1 exhibited stacking in the edge-to-face style and the unit cell was quite large with six pillar[5] arenes and 14 dichloroethane molecules (see $\mathrm{ESI}^{\dagger}$ ).

In the ${ }^{1} \mathrm{H}$ NMR spectrum of Pillar-1, the methylene protons (H2) split into two doublets with a $1: 1$ ratio due to their locations in the inner and outer spaces of the electron-rich cyclic structure, which were shielded and deshielded, respectively; this indicates no or slow mobility on the NMR time scale at $25{ }^{\circ} \mathrm{C}$. To investigate the conformational mobility of Pillar-1, variable-temperature ${ }^{1} \mathrm{H}$ NMR spectroscopy was performed in toluene- $d_{8}$ (Fig. 1). No changes were observed in the two doublets corresponding to the methylene protons (H2) even at $90{ }^{\circ} \mathrm{C}$ due to the rigidity of the bulky $t$-butyl groups. Further variable-temperature ${ }^{1} \mathrm{H}$ NMR experiments conducted with pillar[5]arene with bulky isobutyl substituents on the benzene rings showed that the protons coalesced into one peak upon heating above $75^{\circ} \mathrm{C}$, indicating that increasing the branching of the alkoxy groups on the pillar[5] arene ring hindered the conformational mobility. ${ }^{7 \boldsymbol{b}}$

\section{Binding studies}

The host-guest interactions between Pillar-1 and n-octyltrimethyl ammonium hexafluorophosphate (OMA) were investigated using a ${ }^{1} \mathrm{H}$ NMR titration method, as OMA was previously reported to be a good guest species for pillar[5]

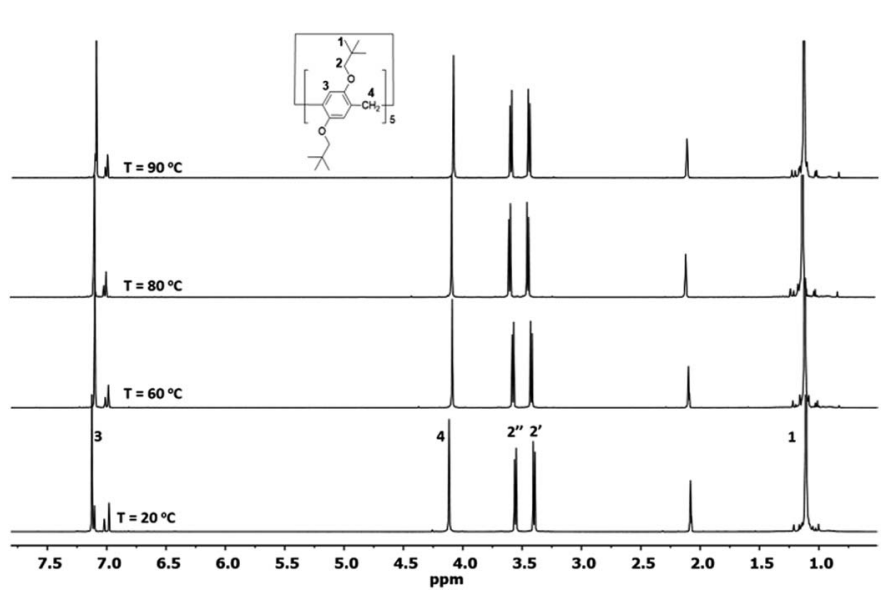

Fig. 1 Variable-temperature ${ }^{1} \mathrm{H}$ NMR spectra (600 MHz, toluene- $d_{8}$ ) of Pillar-1. arenes. ${ }^{7 \boldsymbol{d}, \mathbf{1 4}}$ The ${ }^{1} \mathrm{H}$ NMR spectra of mixtures of OMA (12 mM) and varying concentrations of Pillar-1 in $\mathrm{CDCl}_{3}$ at $25{ }^{\circ} \mathrm{C}$ confirmed host-guest complexation, as evidenced by the upfield shifts of the resonances corresponding to the trimethyl protons (Ha) of OMA. The presence of signals corresponding to complexed (2.35 ppm) and uncomplexed guest OMA (3.18 ppm) suggested a slow exchange on the NMR time scale (see ESI $\dagger$ ). Fig. 2 shows the ${ }^{1} \mathrm{H}$ NMR spectra of Pillar-1 and OMA before and after complexation, along with the corresponding peak assignments, which were based on the host and guest ${ }^{1} \mathrm{H}$ NMR spectra before complexation and 2D NMR spectra of the complex. After complexation, methyl and methylene protons Ha-f shifted upfield significantly, indicating that these protons were located in the shielding region of the cyclic pillar structure. The calculated upfield chemical shift changes of methylene protons $\mathrm{Hb}$, Hc, and methyl protons Ha of OMA were $-3.25,-3.74$, and $0.79 \mathrm{ppm}$, respectively. In contrast, methylene protons $\mathrm{Hg}$-h and methyl protons Hi were located in the deshielding region of the pillararene cavity, as evidenced by the downfield shift of methyl protons $\mathrm{Hj}$ from 0.88 to $1.03 \mathrm{ppm}$ in the ${ }^{1} \mathrm{H}$ NMR spectrum of the complex. These results indicated that the methylene protons were threaded through the cavity of the cyclic host.

The relative position of the protons and through-space ${ }^{1} \mathrm{H}-{ }^{1} \mathrm{H}$ interactions due to the inclusion complex formed between Pillar-1 and OMA were investigated using 2D ROESY NMR spectroscopy. The strong correlation between methylene hydrogen Hc and trimethyl group protons Ha of OMA with the methylene hydrogens of Pillar-1 provided further evidence for the formation of the inclusion complex (Pillar-1つOMA) (see ESI†).

The stoichiometry of the host-guest complex was established using Job's plots, which was formed using the mole fraction of the guest ( $\left.X_{\text {guest }}\right)$ and the difference between the uncomplexed and observed chemical shift change of the trimethyl protons on OMA in ${ }^{1} \mathrm{H}$ NMR multiplied by the mole fraction $\left(X_{\text {guest }}\right)$. The Job's plot of Pillar-1 with OMA in $\mathrm{CDCl}_{3}$ showed a maximum at a mole fraction of 0.5 (Fig. 3a), indicating a 1 : 1 host-to-guest stoichiometric ratio. Further evidence of the

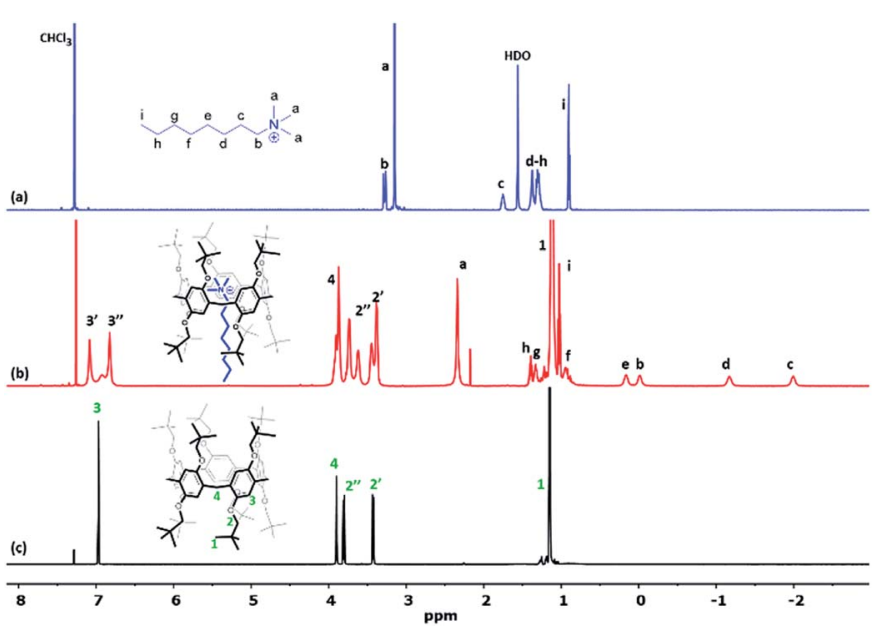

Fig. $2{ }^{1} \mathrm{H}$ NMR spectra $\left(600 \mathrm{MHz}, \mathrm{CDCl}_{3}, 25^{\circ} \mathrm{C}\right)$ of (a) $12 \mathrm{mM} \mathrm{OMA}$, (b) 12 mM OMA and 14 mM Pillar-1, and (c) Pillar-1. 

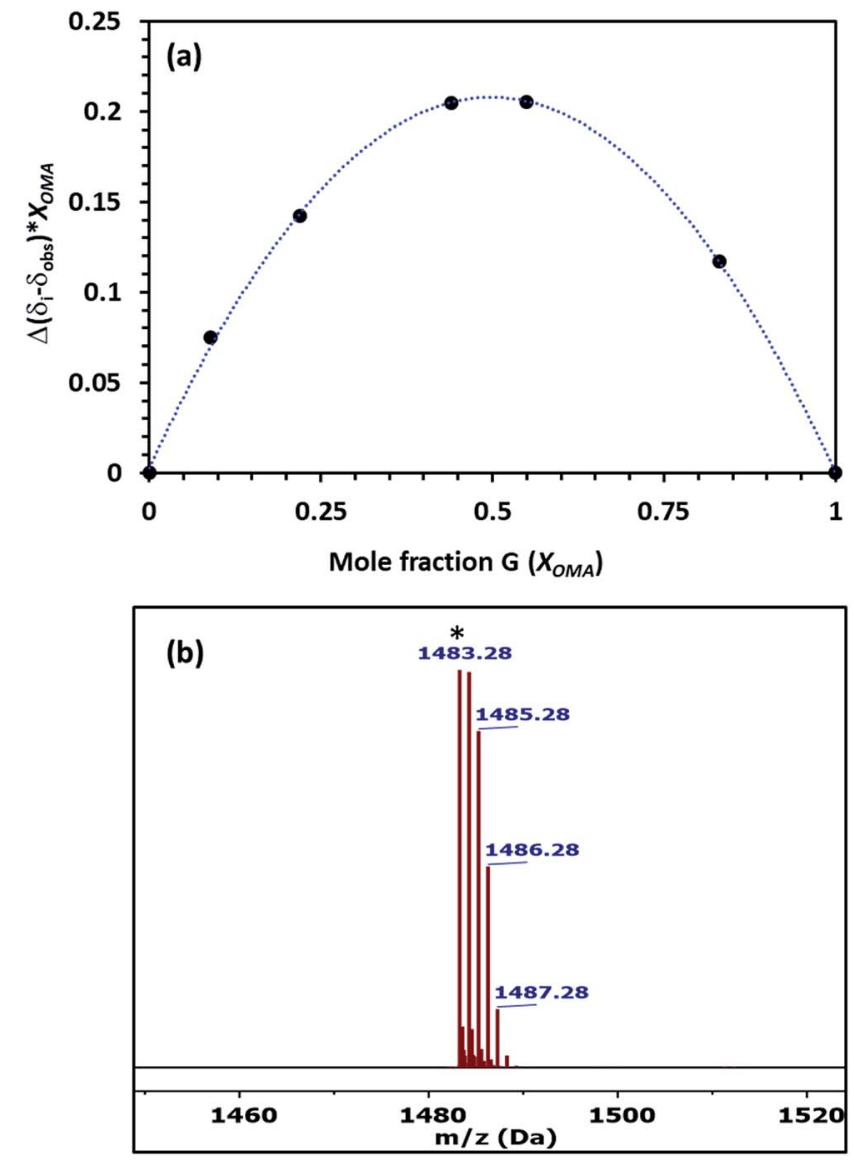

Fig. 3 (a) Job's plot of Pillar-1 with OMA determined from ${ }^{1} \mathrm{H}$ NMR titration in $\mathrm{CDCl}_{3}$ at $25^{\circ} \mathrm{C}$. (b) ES-MS spectrum of [(Pillar-1つOMA)$\left.\mathrm{PF}_{6}\right]^{+}$.

1: 1 complex was obtained via ESI-MS, where the relevant molecular peak at $\mathrm{m} / z=1483.28$ corresponding to [(Pillar-1 + OMA) $\left.-\mathrm{PF}_{6}\right]^{+}$was observed; these results were also in agreement with the results obtained from the ${ }^{1} \mathrm{H}$ NMR titration experiments (Fig. 3b). The association constant for complexation $\left(K_{\mathrm{a}}\right)$ was determined to be $2.9 \times 10^{3} \mathrm{M}^{-1}$ using the integration of the relative peak area of the slowly exchanged protons on the trimethyl group of OMA on the complexed and uncomplexed species. The association constant calculated for Pillar-1 was significantly higher than that of the bulky percyclohexylmethylpillar[5] arene. ${ }^{7 d}$

The pillar[5]arenes are racemic and comprised of a $1: 1$ mixture of the planar chiral (Sp) and (Rp) conformers, as evidenced from their XRD structures. The introduction of bulky groups on pillar[5] arenes is known to restrict the rotation of the units and result in the separation of enantiopure isomers, as demonstrated previously with a pillar[5] arene with bulky cyclohexylmethyl groups. However, attempts to separate enantiopure isomers of Pillar-1 by chiral column HPLC were unsuccessful. Therefore, using our previously reported strategy $^{\mathbf{1 5}}$ we attempted co-cyclization with a benzoxycontaining monomer, which enabled derivatization with a chiral agent $((S)-(+)$-Mosher's acid chloride) after complete

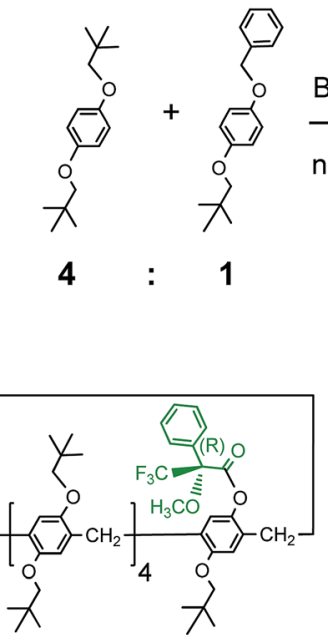

Pillar-4
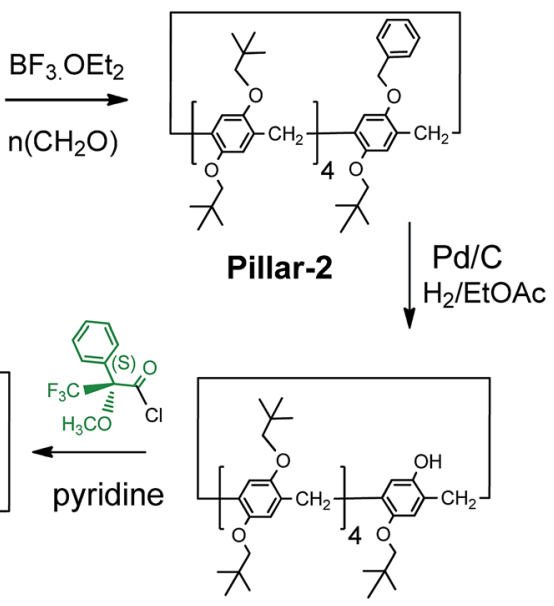

Pillar-3
Scheme 2 Synthesis and derivatization of monohydroxy-pillar[5] arene with (S)-(+)-Mosher's acid chloride.

removal of the benzyl group by catalytic hydrogenation, as shown in Scheme $2 .^{\mathbf{1 6}}$

TLC analysis of synthesized Pillar-4 showed two spots with equal intensities, which were isolated by silica gel column chromatography. Fig. 4a shows the HPLC chromatograms of the crude reaction mixture and isolated $(R)-(+)$-Mosher's ester derivatives. Even though pillar[5]arene has eight possible stereoisomeric conformers, two peaks with equal areas were observed. Both fractions exhibited a peak at $\mathrm{m} / \mathrm{z} 1479.9164$ and 149.9141 corresponding to $[\mathrm{M}+\mathrm{Na}]^{+}$in their HRMS spectra. Fig. 4b shows the ${ }^{19} \mathrm{~F}$ NMR spectra before and after separation by silica gel column chromatography. The ${ }^{19} \mathrm{~F}$ NMR spectrum of the crude reaction mixture showed two signals with a $1: 1$ ratio corresponding to the trifluoromethyl $\left(\mathrm{CF}_{3}\right)$ group, which indicated the presence of two stereoisomers. The $\mathrm{CF}_{3}$ group in the
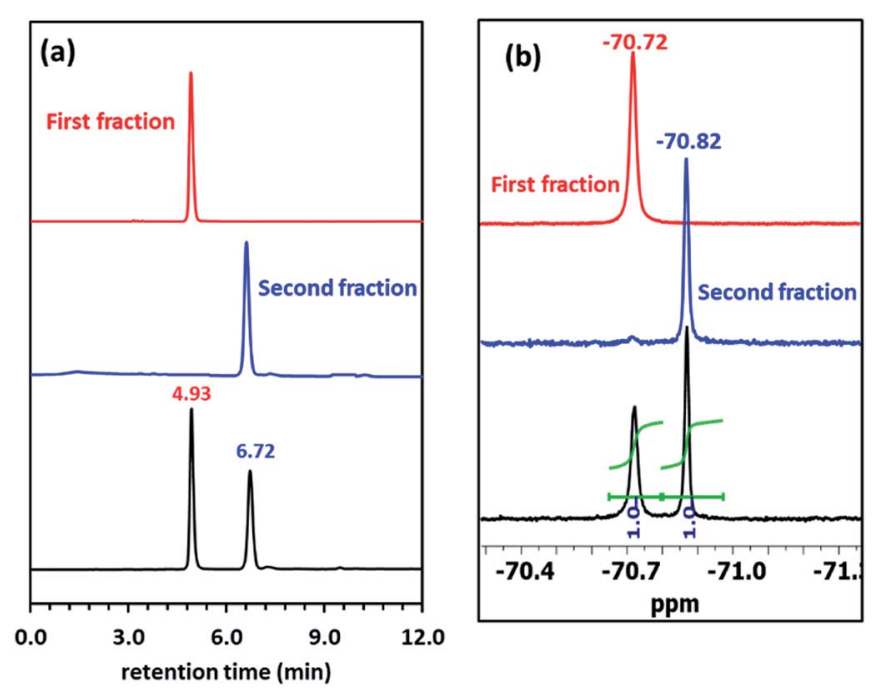

Fig. 4 (a) HPLC traces of Pillar-4 before and after separation. Hexane/ $\mathrm{CHCl}_{3}=95 / 5$ (vol\%) was used as the eluent. (b) ${ }^{19} \mathrm{~F}$ NMR spectra. 
compound from the first fraction resonated at $-70.02 \mathrm{ppm}$, while than that of the second fraction appeared at $-70.87 \mathrm{ppm}$.

Significant differences in the ${ }^{1} \mathrm{H}$ NMR spectra of the isolated fractions were also observed (Fig. 1). The ${ }^{1} \mathrm{H}$ NMR of the first fraction revealed a noticeable upfield shift in the resonance corresponding to one of the bridge methylene protons at $2.81 \mathrm{ppm}$ and methine proton at $6.31 \mathrm{ppm}$ of the aromatic pillar frame; in the second fraction, these protons appeared at $3.35 \mathrm{ppm}$ and $6.68 \mathrm{ppm}$, respectively. Furthermore, the substituent methylene hydrogens $\left(\mathrm{O}-\mathrm{C} \underline{H}_{2}-t \mathrm{Bu}\right)$ of the compound isolated in the first fraction resonated at a higher field compared to those of the second fraction. The shielding effect experienced by the protons in the compound isolated in the first fraction was due to their location in the shielding region of the phenyl group of the Mosher fragment, as evidenced by ${ }^{1} \mathrm{H}_{-}{ }^{1} \mathrm{H}$ ROSEY NMR (see ESI $\dagger$ ). In contrast, the protons corresponding to the Mosher methoxy group (assigned by ${ }^{1} \mathrm{H}_{-}{ }^{13} \mathrm{C}$ HSQC) on the compound isolated in the first fraction resonated at $3.85 \mathrm{ppm}$, while those from the second fraction resonated at $3.56 \mathrm{ppm}$. To further investigate the rotational motion in the diastereomers of Pillar-4, HPLC measurements were carried out. No new peaks were detected in either fraction, indicating that the diastereomers did not racemize.

\section{Experimental}

\section{Materials and methods}

Nuclear magnetic resonance (NMR) spectroscopy was carried out on Bruker Avance II $600 \mathrm{MHz}$ (Germany), Bruker DPX 400 (Germany), or Agilent $400 \mathrm{MHz}$ (UK) spectrometers. Electron impact ionization (EI) mass spectrometry was performed on a Thermo Scientific DFS High Resolution GC/MS (Germany) mass spectrometer. Electro-spray ionization was carried out in high resolution mode using a Waters Xevo G2-S Qtof (Germany) LC MS/MS mass spectrometer. Single crystal data analysis was carried out on an R-AXIS RAPID II, Rigaku, (Japan) diffractometer. The data were collected at $-123{ }^{\circ} \mathrm{C}$ (Oxford Cryosystems, UK). High performance liquid chromatography (HPLC) was carried out on a Waters 1525 (USA) HPLC system equipped with a UV-Vis detector (Waters 2487 dual $\lambda$ absorbance detector). The details were as follows: Waters Spherisorb® $5 \mu \mathrm{m} \mathrm{NH} \mathrm{NH}_{2}$; solvent polarity: hexane : chloroform (95: 5, v/v); run time: $12 \mathrm{~min}$; flow rate: $1 \mathrm{~mL}$ per min. Circular dichroism (CD) spectra were recorded on a Jasco J-815 CD (Germany) spectrometer. Ultraviolet-visible (UV-vis) spectra were recorded on a Varian Cary 5 Agilent (USA) spectrophotometer. Flash column chromatography was performed on silica gel (silica gel 60, 230-400 mesh ASTM, EMD Millipore, Merck KGaA, Germany). DMF, dichloroethane, and ethyl acetate were distilled prior to use in the hydrogenation reaction. All other reagents and solvents were of reagent grade purity and were used as received from commercial suppliers without further purification.

\section{Synthesis of $\boldsymbol{n}$-octyltrimethylammonium hexafluorophosphate (OMA) ${ }^{15 c}$}

Chlorooctane (2 mL; $11.76 \mathrm{mmol})$ and Trimethylamine $(4.2 \mathrm{M}$ solution in ethanol; $2.8 \mathrm{~mL} ; 11.76 \mathrm{mmol}$ ) were taken in $10 \mathrm{~mL}$ round bottom flask and the reaction mixture was refluxed overnight. Ethanol was removed under reduced pressure, then the residue dissolved in deionized water. A solution of ammonium hexafluorophosphate $(2.5 \mathrm{~g} ; 15.3 \mathrm{mmol})$ in $1 \mathrm{~mL}$ deionized water, was added. White precipitate of OMA was formed instantly. The precipitate was collected by filtration, washed with water three times and dried at vacuum oven. Yield, $3.5 \mathrm{~g}$ white solid (11 mmol); 95\%. ${ }^{1} \mathrm{H}$ NMR (600 $\left.\mathrm{MHz} \mathrm{CDCl}_{3}\right) \delta: 0.90$ $(\mathrm{t}, J=7.2, J=7.2,3 \mathrm{H}), 1.31(\mathrm{~m}, 6 \mathrm{H}), 1.37(\mathrm{~m}, 4 \mathrm{H}), 1.75(\mathrm{~m}, 2 \mathrm{H})$, $3.15(\mathrm{~s}, 9 \mathrm{H}), 3.28(\mathrm{~m}, 2 \mathrm{H}) .{ }^{13} \mathrm{C} \mathrm{NMR}\left(150 \mathrm{MHz}, \mathrm{CDCl}_{3}\right), \delta: 14.2$, 22.8, 23.3, 26.2, 29.2, 31.8, 53.4, 67.6. EI-MS: 172.2 [M - $\left.\mathrm{PF}_{6}\right]$.

\section{Synthesis of 4-(benzyloxy)phenol}

Hydroquinone (6.60 g; $60 \mathrm{mmol}$ ) was dissolved in acetone (120 $\mathrm{mL})$ at room temperature and potassium carbonate $(12.40 \mathrm{~g} ; 90$ mmol) was added. The solution was refluxed overnight after adding benzyl bromide $(10.36 \mathrm{~mL}, 40 \mathrm{mmol})$. The solvent was removed by evaporation under reduced pressure and the crude product was extracted with dichloromethane. 4-(Benzyloxy) phenol was then purified by column chromatography using a mixture of dichloromethane and hexane $(60: 40, \mathrm{v} / \mathrm{v})$. Yield $=$ $5.6 \mathrm{~g}, 70 \% .{ }^{1} \mathrm{H}$ NMR $\left(400 \mathrm{MHz}, \mathrm{CDCl}_{3}\right) \delta: 5.01(\mathrm{~s}, 2 \mathrm{H}), 6.77(\mathrm{~m}$, 2H), 6.87 (m, 2H), 7.38 (m, 5H); ${ }^{13} \mathrm{C} \mathrm{NMR} \mathrm{(150} \mathrm{MHz,} \mathrm{CDCl}_{3}$ ), $\delta$ : 71.0, 116.3, 116.3, 127.7, 128.1, 128.8, 137.4, 149.9, 153.2. HRMS: calc.: 200.0832 (for $\mathrm{C}_{13} \mathrm{H}_{12} \mathrm{O}_{2} ;[\mathrm{M}]^{+}$); found: 200.0833 .

\section{Synthesis of 1-(benzyloxy)-4-(neopentyloxy)benzene}

In a sealed tube, 4-(benzyloxy)phenol (4.00 g; $20 \mathrm{mmol}$ ) was dissolved in DMF $(20 \mathrm{~mL})$ at room temperature and potassium carbonate (4.14 g; $30 \mathrm{mmol}$ ) was added with stirring. This solution was stirred for about $30 \mathrm{~min}$ and then 1-iodo-2,2dimethylpropane $(2.65 \mathrm{~mL}, 20 \mathrm{mmol})$ was added. The sealed tube was heated at $125{ }^{\circ} \mathrm{C}$ for $24 \mathrm{~h}$. The crude product precipitated upon addition of water $(200 \mathrm{~mL})$ to the reaction mixture. The precipitate was collected, washed with water $(2 \times 50 \mathrm{~mL})$, and dried over anhydrous $\mathrm{Na}_{2} \mathrm{SO}_{4}$. The product was purified by column chromatography using dichloromethane/hexane (50:50, v/v). Yield $=3.5 \mathrm{~g}, 65 \% .{ }^{1} \mathrm{H} \mathrm{NMR}\left(600 \mathrm{MHz}, \mathrm{CDCl}_{3}\right) \delta$ : $1.08(\mathrm{~s}, 9 \mathrm{H}), 3.56(\mathrm{~s}, 2 \mathrm{H}), 5.03(\mathrm{~s}, 2 \mathrm{H}), 6.85(\mathrm{~m}, 2 \mathrm{H}), 6.91(\mathrm{~m}, 2 \mathrm{H})$, $7.32(\mathrm{~m}, 1 \mathrm{H}), 7.39(\mathrm{~m}, 2 \mathrm{H}), 7.44(\mathrm{~m}, 2 \mathrm{H}) ;{ }^{13} \mathrm{C}$ NMR $(150 \mathrm{MHz}$, $\left.\mathrm{CDCl}_{3}\right), \delta: 26.8,32.1,70.9,78.8,115.6,116.0,127.6,128.0,128.7$, 137.6, 153.0, 154.3. HRMS: calc.: 270.1614 (for $\mathrm{C}_{18} \mathrm{H}_{22} \mathrm{O}_{2}$; [M] $]^{+}$); found: 270.1614 .

\section{Pillar-1}

Paraformaldehyde $(0.93 \mathrm{~g}, 30 \mathrm{mmol})$ was added to a solution of 1,4-bis(neopentyloxy)benzene $(2.50 \mathrm{~g}, 10 \mathrm{mmol})$ in dry dichloroethane $(30 \mathrm{~mL})$ under a nitrogen atmosphere. Boron trifluoride diethyl etherate $\left(\mathrm{BF}_{3} \cdot \mathrm{OEt}_{2}\right),(1.25 \mathrm{~mL}, 10 \mathrm{mmol})$ was then added to the solution, and the mixture was stirred at room temperature for $30 \mathrm{~min}$. $\mathrm{MeOH}(100 \mathrm{~mL})$ was poured into the reaction mixture, the solution was concentrated, and the resulting residue was dissolved in $\mathrm{CH}_{2} \mathrm{Cl}_{2}(100 \mathrm{~mL})$. The solution was then washed with aqueous $\mathrm{NaHCO}_{3}(2 \times 50 \mathrm{~mL})$ and $\mathrm{H}_{2} \mathrm{O}(50 \mathrm{~mL})$. The organic layer was dried over anhydrous $\mathrm{Na}_{2} \mathrm{SO}_{4}$, concentrated under vacuum, and subjected to silica gel 
chromatography (hexane/ $\mathrm{CH}_{2} \mathrm{Cl}_{2} ; 40: 60, \mathrm{v} / \mathrm{v}$ ) to give Pillar-1 as a white solid $(680 \mathrm{mg}, 26 \%) .{ }^{1} \mathrm{H}$ NMR $\left(600 \mathrm{MHz}, \mathrm{CDCl}_{3}\right) \delta: 1.15$ (S, 90H), 3.43 (d, $J=8.4,10 \mathrm{H}), 3.80(\mathrm{~d}, J=8.4,10 \mathrm{H}), 3.90$ (s, $10 \mathrm{H}), 6.97$ (s, 10H); ${ }^{13} \mathrm{C}$ NMR (150 MHz, $\left.\mathrm{CDCl}_{3}\right), \delta: 27.1,29.0$, 32.1, 79.8, 115.5, 128.6, 150.4. HRMS: calc.: 1311.9742 (for $\mathrm{C}_{85} \mathrm{H}_{131} \mathrm{O}_{10} ;[\mathrm{M}+\mathrm{H}]^{+}$); found: 1311.9762 .

\section{Pillar-2}

Paraformaldehyde $(0.93 \mathrm{~g}, 30 \mathrm{mmol})$ was added to a solution of 1,4bis(neopentyloxy)benzene $(2.0 \mathrm{~g}, 8 \mathrm{mmol})$ and 1-(benzyloxy)-4(neopentyloxy)benzene $(0.54 \mathrm{~g}, 2 \mathrm{mmol})$ in dry dichloroethane (30 $\mathrm{mL})$ under a nitrogen atmosphere. $\mathrm{BF}_{3} \cdot \mathrm{OEt}_{2}(1.25 \mathrm{~mL}, 10 \mathrm{mmol})$ was then added to the solution, and the mixture was heated to $35{ }^{\circ} \mathrm{C}$ for $30 \mathrm{~min}$. $\mathrm{MeOH}(50 \mathrm{~mL})$ was poured into the reaction mixture, the solution was concentrated, and the resulting residue was dissolved in $\mathrm{CH}_{2} \mathrm{Cl}_{2}(100 \mathrm{~mL})$. The solution was then washed with aqueous $\mathrm{NaHCO}_{3}(2 \times 50 \mathrm{~mL})$ and $\mathrm{H}_{2} \mathrm{O}(50 \mathrm{~mL})$. The organic layer was dried over $\mathrm{Na}_{2} \mathrm{SO}_{4}$, concentrated under vacuum, and subjected to silica gel chromatography (hexane $/ \mathrm{CH}_{2} \mathrm{Cl}_{2} ; 85: 15 \mathrm{v} / \mathrm{v}$ ) to give Pillar-2 as a white solid $(320 \mathrm{mg}, 12 \%) .{ }^{1} \mathrm{H}$ NMR $\left(600 \mathrm{MHz}, \mathrm{CDCl}_{3}\right) \delta: 0.95(\mathrm{~S}$, $9 \mathrm{H}), 1.12(\mathrm{~m}, 72 \mathrm{H}), 3.05(\mathrm{~d}, J=8.4,1 \mathrm{H}), 3.13(\mathrm{~d}, J=9.0,1 \mathrm{H}), 3.41(\mathrm{~m}$, $8 \mathrm{H}), 3.75(\mathrm{~m}, 8 \mathrm{H}), 3.86(\mathrm{~m}, 10 \mathrm{H}), 4.90(\mathrm{~d}, J=11.4,1 \mathrm{H}), 5.13(\mathrm{~d}, J=$ 11.4), $6.84(\mathrm{~s}, 1 \mathrm{H}), 6.87(\mathrm{~s}, 1 \mathrm{H}), 6.89(\mathrm{~s}, 1 \mathrm{H}), 6.92(\mathrm{~s}, 1 \mathrm{H}), 6.94(\mathrm{~m}, 5 \mathrm{H})$, $7.07(\mathrm{~s}, 1 \mathrm{H}), 7.32(\mathrm{~m}, 3 \mathrm{H}), 7.48(\mathrm{~m}, 2 \mathrm{H}) ;{ }^{13} \mathrm{C} \mathrm{NMR}\left(150 \mathrm{MHz}, \mathrm{CDCl}_{3}\right)$, $\delta: 14.3,22.9,27.2,27.2,27.2,27.3,27.3,27.3,27.4,28.3,28.5,29.2$, 29.5, 30.6, 31.8, 32.1, 32.3, 32.3, 32.3, 70.6, 78.8, 79.4, 79.9, 79.9, 79.9, 80.0, 80.4, 114.9, 115.3, 115.3, 115.5, 115.6, 115.6, 115.8, 115.9, $116.0,116.0,127.5,127.8,127.9,128.4,128.5,128.7,128.8,128.8$, 128.9, 129.1, 129.1, 129.2, 138.3, 150.1, 150.2, 150.3, 150.4, 150.5, 150.6, 150.7, 150.7, 150.8, 150.9. HRMS: calc.: 1353.9249 (for $\mathrm{C}_{87} \mathrm{H}_{126} \mathrm{O}_{10} \mathrm{Na}$; $[\mathrm{M}+\mathrm{Na}]^{+}$); found: 1353.9218 .

\section{Pillar-3}

$50 \mathrm{mg}$ of Pd/C (5\%) was added to a solution of Pillar-2 (0.200 g; $0.15 \mathrm{mmol}$ ) in $30 \mathrm{~mL}$ of anhydrous ethyl acetate. Air was evacuated from the apparatus used for the catalytic hydrogenation and it was filled with $\mathrm{H}_{2}$. After the theoretical quantity of hydrogen was absorbed, the $\mathrm{Pd} / \mathrm{C}$ catalyst was filtered off and carefully washed with ethyl acetate. The combined filtrate was evaporated to give Pillar-3 as a white solid $(0.180 \mathrm{~g}, 97 \%) .{ }^{1} \mathrm{H}$ NMR (600 MHz, $\left.\mathrm{CDCl}_{3}\right) \delta: 0.99(\mathrm{~s}, 9 \mathrm{H}), 1.11(\mathrm{~m}, 72 \mathrm{H}), 3.35(\mathrm{~m}$, 1H), $3.46(\mathrm{~m}, 6 \mathrm{H}), 3.50(\mathrm{~m}, 1 \mathrm{H}), 3.65(\mathrm{~m}, 8 \mathrm{H}), 3.77(\mathrm{~m}, 5 \mathrm{H}), 3.93$ $(\mathrm{m}, 5 \mathrm{H}), 4.13(\mathrm{~d}, J=7.2,1 \mathrm{H}), 4.16(\mathrm{~d}, J=7.2,1 \mathrm{H}), 6.76(\mathrm{~m}, 3 \mathrm{H})$, $6.84(\mathrm{~s}, 1 \mathrm{H}), 6.89(\mathrm{~s}, 1 \mathrm{H}), 6.91(\mathrm{~s}, 1 \mathrm{H}), 6.94(\mathrm{~s}, 1 \mathrm{H}), 6.99(\mathrm{~s}, 1 \mathrm{H})$, $7.00(\mathrm{~s}, 1 \mathrm{H}), 7.01(\mathrm{~s}, 1 \mathrm{H}) ;{ }^{13} \mathrm{C}$ NMR (150 MHz, CDCl3), $\delta: 22.9$, 27.1, 27.2, 27.2, 27.3, 27.3, 27.3, 27.4, 28.6, 29.0, 29.7, 29.9, 30.0, 31.4, 32.2, 32.2, 32.3, 32.3, 32.3, 32.4, 32.4, 79.5, 79.8, 79.9, 80.0, 80.1, 80.2, 80.3, 115.2, 115.5, 115.6, 115.7, 115.7, 115.7, 115.8, $116.0,118.8,125.8,127.3,128.8,128.9,129.0,129.2,129.8$, $130.0,147.2,150.3,150.5,150.6,150.6,150.7,150.9,150.9$. HRMS: calc.: 1263.8779 (for $\mathrm{C}_{80} \mathrm{H}_{120} \mathrm{O}_{10} \mathrm{Na}$; $[\mathrm{M}+\mathrm{Na}]^{+}$); found: 1263.8757.

\section{Derivatization reaction}

Pillar-3 (100 mg, $0.08 \mathrm{mmol}$ ) was dissolved in $1 \mathrm{~mL}$ distilled pyridine, and $20 \mathrm{mg}$ of dimethylaminopyridine (DMAP) was added and stirred at $0{ }^{\circ} \mathrm{C}$ for $15 \mathrm{~min}$. (S)-(+)- $\alpha$-methoxy- $\alpha$-trifluoromethylphenylacetyl chloride $(50 \mu \mathrm{L}, 0.267 \mathrm{mmol})$ was added and the mixture was stirred for $3 \mathrm{~h}$ at room temperature. The reaction mixture was poured into $20 \mathrm{~mL}$ aqueous $\mathrm{HCl}(4 \mathrm{M})$. The resulting white precipitate was filtered, and washed with distilled water $(2 \times 50 \mathrm{~mL})$. TLC analysis showed two distinct spots, which corresponded to the diastereomers. The two diastereomers were separated by column chromatography using hexane/dichloromethane $(85: 15, \mathrm{v} / \mathrm{v})$. Overall yield $=101 \mathrm{mg}$, $87 \%$.

\section{First fraction}

Yield $=49 \mathrm{mg}(42 \%) .{ }^{1} \mathrm{H}$ NMR $\left(600 \mathrm{MHz}, \mathrm{CDCl}_{3}\right) \delta: 1.01(\mathrm{~s}, 9 \mathrm{H})$, $1.09(\mathrm{~m}, 63 \mathrm{H}), 1.22(\mathrm{~s}, 9 \mathrm{H}), 2.84(\mathrm{~d}, J=18.0,1 \mathrm{H}) 3.24(\mathrm{~m}, 1 \mathrm{H})$, $3.31(\mathrm{~m}, 1 \mathrm{H}), 3.38(\mathrm{~m}, 7 \mathrm{H}), 3.79(\mathrm{~m}, 21 \mathrm{H}), 6.32(\mathrm{~s}, 1 \mathrm{H}), 6.92(\mathrm{~m}$, $8 \mathrm{H}), 7.16(\mathrm{~s}, 1 \mathrm{H}), 7.41(\mathrm{~m}, 3 \mathrm{H}), 7.72(\mathrm{~m}, 2 \mathrm{H}) ;{ }^{13} \mathrm{C}$ NMR $(150 \mathrm{MHz}$, CDCl3), $\delta: 22.9,27.2,27.3,27.5,28.9,29.1,29.1,29.2,29.3,31.8$, $32.2,32.2,32.3,32.3,32.4,56.9,79.6,79.6,79.9,80.0,80.0,80.1$, $114.9,115.0,115.5,115.5,115.8,115.8,115.9,116.0,124.3$, $127.3,127.4,128.0,128.7,128.8,129.0,129.1,129.1,129.2$, $129.3,130.1,131.8,140.2,150.2,150.4,150.6,150.6,150.7$, 150.8, 150.8, 150.9, 155.4, 166.4. HRMS: calc.: 1479.9177 (for $\mathrm{C}_{90} \mathrm{H}_{127} \mathrm{O}_{12} \mathrm{~F}_{3} \mathrm{Na} ;[\mathrm{M}+\mathrm{Na}]^{+}$); found: 1479.9164 .

\section{Second fraction}

Yield $=52 \mathrm{mg}(45 \%) .{ }^{1} \mathrm{H}$ NMR $\left(600 \mathrm{MHz}, \mathrm{CDCl}_{3}\right) \delta: 0.96(\mathrm{~s}, 9 \mathrm{H})$, $1.08(\mathrm{~m}, 72 \mathrm{H}), 3.34(\mathrm{~m}, 10 \mathrm{H}), 3.53(\mathrm{~s}, 3 \mathrm{H}), 3.62(\mathrm{~m}, 18 \mathrm{H}), 6.65(\mathrm{~s}$, 1H), $6.90(\mathrm{~m}, 8 \mathrm{H}), 7.05(\mathrm{~s}, 1 \mathrm{H}), 7.43(\mathrm{~m}, 3 \mathrm{H}), 7.64(\mathrm{~m}, 2 \mathrm{H}) ;{ }^{13} \mathrm{C}$ $\operatorname{NMR}\left(150 \mathrm{MHz}, \mathrm{CDCl}_{3}\right), \delta: 27.3,27.3,27.3,27.3,28.8,29.1,29.3$, 29.5, 29.9, 32.2, 32.3, 32.3, 55.6, 79.8, 79.8, 79.9, 80.0, 80.0, 80.1, 80.2, 115.0, 115.4, 115.4, 115.5, 115.7, 115.7, 115.9, 116.0, 116.0, 124.1, 127.5, 127.7, 128.4, 128.6, 128.9, 129.0, 129.0, 129.0, $129.3,129.3,129.3,129.3,130.1,131.7,132.0,140.4,150.2$, 150.3, 150.6, 150.6, 150.7, 150.8, 151.0, 151.1, 155.6, 166.5 . HRMS: calc.: 1479.9177 (for $\mathrm{C}_{90} \mathrm{H}_{127} \mathrm{O}_{12} \mathrm{~F}_{3} \mathrm{Na}$; $[\mathrm{M}+\mathrm{Na}]^{+}$); found: 1479.9141.

\section{Preparation of single crystals for X-ray diffraction}

Crystals suitable for single crystal X-ray diffraction of Pillar-1 were grown by diffusion using dichloroethane and hexane. The single crystal data were collected on a diffractometer (R-AXIS RAPID, Rigaku, Japan) using Rigaku's Crystal clear software package at $-123^{\circ} \mathrm{C}$. The structure was solved and refined using the Bruker SHELXTL Software Package (structure solution program: SHELXS-97; refinement program: SHELXL-97). CCDC 1561385. $\dagger$

\section{${ }^{1} \mathrm{H}$ NMR titrations}

A $0.5 \mathrm{~mL}$ sample of OMA was prepared at $12.0 \mathrm{mM}$ in chloroform- $d$. All titration experiments were carried out in an NMR tube at $298 \mathrm{~K}$, and ${ }^{1} \mathrm{H}$-NMR spectra were recorded upon successive addition of the appropriate amount of the host (Pillar-1). The association constant was calculated from the complexed and uncomplexed trimethyl groups of OMA at 2.35 and $3.18 \mathrm{ppm}$, respectively at $80 \%$ complexation. 


\section{Conclusions}

In conclusion, we successfully synthesized a pillar[5]arene with bulky neopentyl groups on both rims. Variable-temperature ${ }^{1} \mathrm{H}$ NMR spectroscopy experiments showed that the bulky substituents inhibited the rotational mobility. Complexation between Pillar-1 and OMA was studied by ${ }^{1} \mathrm{H}-\mathrm{NMR}$ and ES-MS, and the formation of a 1:1 inclusion complex Pillar-1 $\supset$ OMA was confirmed. Monohydroxy-functionalized pillar[5]arene Pillar-3 was synthesized by co-cyclization of hydroquinone derivatives bearing monobenzyl substituents followed by catalytic hydrogenation over palladium in charcoal in anhydrous ethyl acetate. The pure diastereomeric pair was separated by column chromatography after derivatization with $(S)-(+)$-Mosher's acid chloride to produce Pillar-3. The diastereomeric purity was confirmed by chiral-column HPLC and ${ }^{19} \mathrm{~F}$ NMR analysis. No racemization was observed at $40^{\circ} \mathrm{C}$ for $72 \mathrm{~h}$. Further studies and modification of the planar-chiral functionalized pillar[5]arene host in terms of their use as chiral guest receptors and building blocks for chiral supramolecular architectures are underway in our laboratory.

\section{Conflicts of interest}

There are no conflicts to declare.

\section{Acknowledgements}

The support of the University of Kuwait, received through research grant no. SC03/16, and the facilities of ANALAB and SAF (grant no. GS01/01, GS03/01, GS01/03, GS01/05, and GS03/ 08) are gratefully acknowledged.

\section{Notes and references}

1 (a) K. E. Krakowiak, J. S. Bradshaw and D. J. ZameckaKrakowiak, Chem. Rev., 1989, 89, 929-972; (b) J. S. Bradshaw and R. M. Izatt, Acc. Chem. Res., 1997, 30, 338-345; (c) G. W. Gokel, W. M. Levy and M. E. Weber, Chem. Rev., 2004, 104, 2723-2750.

2 (a) A. Harada, A. Hashidzume, H. Yamaguchi and Y. Takashima, Chem. Rev., 2009, 109, 5974-6023; (b) C. D. Gutsche, Calixarenes Revisited, Royal Society of Chemistry, Cambridge, 2nd edn, 2000; (c) C. D. Gutsche, Calixarenes, An Introduction, Royal Society of Chemistry, Cambridge, 2008; (d) E. Botana, E. Da Silva, J. BenetBuchholz, P. Ballester and J. de Mendoza, Angew. Chem., Int. Ed., 2007, 46, 198-201.

3 (a) K. Kim, Chem. Soc. Rev., 2002, 31, 96-107; (b) A. E. Kaifer, W. Li, S. Silvi and V. Sindelar, Chem. Commun., 2012, 48, 6693.

4 (a) A. Harada, Acc. Chem. Res., 2001, 34, 456-467; (b) L. Zhu, D. Zhang, D. Qu, Q. Wang, X. Ma and H. Tian, Chem. Commun., 2010, 46, 2587-2589; (c) K.-R. Wang, D.-S. Guo, B.-P. Jiang and Y. Liu, Chem. Commun., 2012, 48, 3644-3646. 5 (a) N. Morohashi, F. Narumi, N. Iki, T. Hattori and S. Miyano, Chem. Rev., 2006, 106, 5291-5316; (b) W. Maes and
W. Dehaen, Chem. Soc. Rev., 2008, 37, 2393-2402; (c) M.-X. Wang, Acc. Chem. Res., 2012, 45, 182-195.

6 (a) F. Diederich, Cyclophanes, The Royal Society of Chemistry, Cambridge, 1991; (b) J. C. Barnes, M. Juríček, N. L. Strutt, M. Frasconi, S. Sampath, M. A. Giesener, P. L. McGrier, C. J. Bruns, C. L. Stern, A. A. Sarjeant and J. F. Stoddart, J. Am. Chem. Soc., 2013, 135, 183; (c) H.-Y. Gong, B. M. Rambo, E. Karnas, V. M. Lynch and J. L. Sessler, Nat. Chem., 2010, 2, 406.

7 (a) T. Ogoshi, S. Kanai, S. Fujinami, T. A. Yamagishi and Y. Nakamoto, J. Am. Chem. Soc., 2008, 130, 5022-5023; (b) C. Han, F. Ma, Z. Zhang, B. Xia, Y. Yu and F. Huang, Org. Lett., 2010, 12, 4360-4363; (c) Z. Li, J. Yang, J. He, Z. Abliz and F. Huang, Org. Lett., 2014, 16, 2065-2069; (d) T. Ogoshi, K. Masaki, R. Shiga, K. Kitajima and T.-a. Yamagishi, Org. Lett., 2011, 13, 1264-1266; (e) T. Ogoshi, Y. Nishida, T.-a. Yamagishi and Y. Nakamoto, Macromolecules, 2010, 43, 3145-3147; $(f)$ H. Li, Y. Yang, F. Xu, T. Liang, H. Wena and W. Tian, Chem. Commun., 2019, 55, 271-285; ( $g$ ) W. Feng, M. Jin, K. Yang, Y. Pei and Z. Pei, Chem. Commun., 2018, 54, 13626-13640.

8 (a) N. L. Strutt, R. S. Forgan, J. M. Spruell, Y. Y. Botros and J. F. Stoddart, J. Am. Chem. Soc., 2011, 133, 5668-5671; (b) N. Strutt, D. Fairen-Jimenez, J. Iehl, M. Lalonde, R. Snurr, O. K. Farha, J. T. Hupp and J. F. Stoddart, J. Am. Chem. Soc., 2012, 134, 17436-17439; (c) T. Ogoshi, K. Kida and T. Yamagishi, J. Am. Chem. Soc., 2012, 134, 20146-20150; (d) C. Li, S. Chen, J. Li, K. Han, M. Xu, B. Hu, Y. Yu and X. Jia, Chem. Commun., 2011, 47, 11294-11296; (e) C. Li, K. Han, J. Li, H. Zhang, J. Ma, X. Shu, Z. Chen, L. Weng and X. Jia, Org. Lett., 2012, 14, 42-45; $(f)$ T. Ogoshi, K. Demachi, K. Kitajima and T.-A. Yamagishi, Chem. Commun., 2011, 47, 10290-10292; (g) T. Ogoshi, K. Masaki, R. Shiga, K. Kitajima and T. Yamagishi, Org. Lett., 2011, 13, 1264-1266.

9 (a) T. Ogoshi, T. Aoki, K. Kitajima, S. Fujinama, T. A. Yamagishi and Y. Nakamoto, J. Org. Chem., 2011, 76, 328-331; (b) Y. Chen, M. He, B. Li, L. Wang, H. Meier and D. Cao, RSC Adv. , 2013, 3, 21405-21408; (c) J. Han, X. Hou, C. Ke, H. Zhang, N. L. Strutt, C. L. Stern and J. F. Stoddart, Org. Lett., 2015, 17, 3260-3263.

10 (a) C. Han, Z. Zhang, G. Yu and F. Huang, Chem. Commun., 2012, 48, 9876-9878; (b) T. Ogoshi, D. Yamafuji, D. Kotera, T. Aoki, S. Fujinami and T.-A. Yamagishi, J. Org. Chem., 2012, 77, 11146-11152; (c) M. Pan and M. Xue, Eur. J. Org. Chem., 2013, 4787-4793.

11 (a) N. L. Strutt, R. S. Forgan, J. M. Spruell, Y. Y. Botros and J. F. Stoddart, J. Am. Chem. Soc., 2011, 133, 5668; (b) N. L. Strutt, D. Fairen-Jimenez, J. Iehl, M. B. Lalonde, R. Q. Snurr, O. K. Farha, J. T. Hupp and J. F. Stoddart, J. Am. Chem. Soc., 2012, 134, 17436.

12 (a) T. Ogoshi, R. Shiga, M. Hashizume and T. Yamagishi, Chem. Commun., 2011, 47, 6927-6929; (b) W. B. Hu, W.-J. Hu, X.-L. Zhao, Y. A. Liu, J. S. Li, B. Jiang and K. Wen, J. Org. Chem., 2016, 81, 3877-3881; (c) G. Yu, Y. Ma, C. Han, Y. Yao, G. Tang, Z. Mao, C. Gao and F. Huang, J. Am. Chem. Soc., 2013, 135, 10310-10313. 
13 (a) S. P. Simeonov, J. P. M. Nunes, K. Guerra, V. B. Kurteva and C. A. M. Afonso, Chem. Rev., 2016, 116, 5744-5893; (b) S. Arae and M. Ogasawara, Tetrahedron Lett., 2015, 56, 1751-1761; (c) R. Deng, Y. Huang, X. Ma, G. Li, R. Zhu, B. Wang, Y. Kang and Z. Gu, J. Am. Chem. Soc., 2014, 136, 4472-4475; (d) Y. Morisaki, M. Gon, T. Sasamori, N. Tokitoh and Y. Chujo, J. Am. Chem. Soc., 2014, 136, 3350-3353; (e) X. Liu, Y. Ma, W. Duan, F. He, L. Zhao and C. Song, J. Org. Chem., 2011, 76, 1953-1956; $(f)$ R. Fiesel, J. Huber, U. Apel, V. Enkelmann, R. Hentschke and U. Scherf, Macromol. Chem. Phys., 1997, 198, 2623-2650.

14 (a) T. Ogoshi, R. Shiga, T.-a. Yamagishi and Y. Nakamoto, J. Org. Chem., 2011, 76, 618-622; (b) Z. Zhang, B. Xia, C. Han, Y. Yu and F. Huang, Org. Lett., 2010, 12, 3285-3287.
15 (a) T. F. Al-Azemi, M. Vinodh, F. H. Alipour and A. A. Mohamod, J. Org. Chem., 2017, 82, 10945-10952; (b) T. F. Al-Azemi, A. A. Mohamod, M. Vinodh and F. H. Alipour, Org. Chem. Front., 2018, 5, 10-18; (c) T. F. AlAzemi, M. Vinodh, F. H. Alipour and A. A. Mohamod, Org. Biomol. Chem., 2018, 16, 7513-7517; (d) P. DemayDrouhard, K. Du, K. Samanta, X. Wan, W. Yang, R. Srinivasan, A. C.-H. Sue and H. Zuilhof, Org. Lett., 2019, 21(11), 3976-3980.

16 T. F. Al-Azemi, M. Vinodh, F. H. Alipour and A. A. Mohamod, Org. Chem. Front., 2019, 6, 603-610. 